\title{
Relationship between social competences and the sense of general mental health and intensity of stress among nurses
}

\author{
Agnieszka Chrzan-Rodak ${ }^{\mathrm{A} \bowtie}$, Barbara Ślusarska ${ }^{\mathrm{B}}$, Grzegorz Nowicki' ${ }^{\mathrm{C}}$ Alina Deluga ${ }^{\mathrm{D}}$, Agnieszka Bartoszek ${ }^{\mathrm{E}}$
}

Medical University of Lublin, Department of Family Medicine and Environmental Nursing, ul. Staszica 4-6, 20-081 Lublin, Poland

A ORCID: 0000-0001-8786-4079; B ORCID: 0000-0003-0101-9216; C ORCID: 0000-0002-0503-8847; $\quad$ D ORCID: 0000-0002-2881-8598; E ORCID: 0000-0003-0974-0761

$\triangle$ agnieszkachrzan607@gmail.com

\begin{abstract}
Introduction: Social competences are indispensable in occupations reliant on interpersonal interactions, such as in medical professions, e.g. nursing, conditioning not only the effective construction of interpersonal relationships, but ever more often emphasizing a positive impact on strengthening coping skills in stressful situations. The object of our study was to assess the connection of social competences with the sense of general mental health and intensity of stress in the group of nurses.

Materials and methods: In the study took part 291 nurses (ages $23-63$, mean job seniority 11 years, $S D=10.22$ ). We used the Social Competence Questionnaire (KKS) according to Anna Matczak, the Perceived Stress Scale (PSS-10), as adapted by Zygfryd Juczyński and Nina Ogińska-Bulik, and the General Health Questionnaire (GHQ-28) in the adaptation of Zofia Makowska and Dorota Merecz to collect information for the study.
\end{abstract}

Results: Stress intensity among respondents averaged 16.83 points (SD $=4.47$ ). In the 4 analyzed indicators of the GHQ-28, the mean point score was: somatic symptoms $M=8.45$, anxiety and insomnia $\mathrm{M}=8.75$, functional disorders $\mathrm{M}=8.07$, depression symptoms $M=2.46 .38 .1 \%$ of the results of the level of general mental health were in the range $5^{-6}$, which is the average level of mental health perceived in the group of nurses.

Conclusions: The level of perceived stress among more than half of the surveyed group of nurses was average (52.6\%). The level of social competences is not significantly correlated with the intensity of stress experienced. The level of general mental health of $38.1 \%$ of the nurses fell in the range of average. The level of social competences significantly correlates with the general mental health status of the nurse respondents $(R=-0.254, p<0.001)$.

Keywords: social skills; nursing; psychosocial deprivation; mental health; professional activity.

\section{INTRODUCTION}

Social competences are a field of interest for an ever-growing group of researchers, and this phenomenon may be promoted by civilizational progress and interest in the development of personal potential [1]. Social competences are skills which are necessary in occupations based on interpersonal interactions, such as in medical professions, e.g. nursing.

Social competences are those used in social situations or interpersonal interactions. Argyle sees social competences as a set of skills thanks to which one can influence other people in social situations. On the other hand, Greenspan claims that these competences are molded by personality traits, e.g. temperament and social intelligence [2]. These competences facilitate coping in social situations, e.g. situations requiring interaction with another person, and are developed as a result of these situations [3]. Social competences allow us to function more effectively in the social environment, and by establishing and maintaining interpersonal relationships, we can have an effective influence on others, or subject ourselves to the influence of others, and also initiate cooperation and communication with other people $[1,4]$. Social competences are related to emotional intelligence, because emotional intelligence forms a predictor of social competences [5].

Social skills are widely studied among various professionals who engage in social relationships. It was noted that social competences have a positive impact on better health and professional satisfaction of employees [6]. Research also points to social competences as a factor for improved coping with stress and a buffer for occupational burnout [7, 8]. It has been proven that there is a correlation between social competences and higher self-esteem in medical staff [9].

The objective of our study was to evaluate the connection of social competences with the sense of general mental health and intensity of stress in a group of nurses. In our work we adopted the following research queries:

1. What is the level of perceived stress and general mental health among nurses?

2. Does the level of perceived stress correlate with the general state of mental health of nurses?

3. Does the level of social competence correlate with the intensity of stress experienced and the general state of mental health of nurses?

\section{MATERIALS AND METHODS}

In the study participated 291 professionally active nurses. The diagnostic survey method was used with the following research tools:

1. Social Competence Questionnaire (KKS) according to Anna Matczak. The questionnaire consists of 90 questions $(60$ 
diagnostic questions and 30 buffer questions). It contains 3 scales describing the de.g.ree of coping in situations requiring assertiveness (A), social exposure (ES) and the intimacy (I). The detailed scales are reliable (alpha 0.80-0.94), and their accuracy was confirmed by exploratory factor analysis. The questionnaire enables calculating the general social competence index [3].

2. Perceived Stress Scale (PSS-10) by Sheldon Cohen, Tom Kamarck and Robin Mermelstein (in the Polish adaptation by Juczyński and Ogińska-Bulik, 2009). The questionnaire contains 10 questions re.g.arding assessment of the intensity of stress associated with life situations over the last month. The respondent answers with a 5-point frequency scale (0-4) In terms ranging from "never" to "very often". According to Polish standards developed for the Perceived Stress Scale-PSS-10, scores between 0-13 (1-4 sten) are treated as low, while results of 20-22 (7-10 sten) are high [10].

3. General Health Questionnaire (GHQ-28) by David Goldberg, in the adaptation by Zofia Makowska and Dorota Merecz (2001), is used to assess the mental health of adults, and allows for screening of people at risk of mental health disorders. The questionnaire consists of 28 questions, measuring 4 areas of symptoms: somatic disorders (A), anxiety (B), functional disorders (C) and depression (D). The theoretical results for scales are in the range 7-28 points, the higher the score, the greater the severity of experienced difficulties [11].

We acquired approval no. KE-0254/224/2018 from the Bioethics Committee of the Medical University of Lublin for the research, and every respondent expressed an oral consent to participate in the study, which was carried out in accordance with the principles of the Helsinki Declaration.

The collected research material was processed using IBM SPSS Statistics (v.25) suite. Quantitative variables were described by their means, standard deviation, quartiles and minimum and maximum values. In the case of qualitative variables, the number and percentage of the cate.g.ories indicated were recorded. Statistical analysis of the data was carried out using the Spearman correlation coefficient, adopting the statistical significance level of $\mathrm{p}<0.05$.

\section{FINDINGS}

In the study participated 272 (93.5\%) women and 19 (6.5\%) men. Nurses were aged $23-63$, with a mean age of 34 years $(\mathrm{SD}=10.35)$.

The average job seniority of the respondents was 11 years ( $\mathrm{SD}=10.22)$. One hundred eighteen $(40.5 \%)$ respondents lived in rural areas, 74 (25.4\%) in towns, and 99 (34\%) in cities. One hundred nineteen $(40.9 \%)$ respondents were single, with the remaining 172 (59.1\%) in a relationship. Most of the nurses had a bachelor de.g.ree in nursing $(n=211,72.5 \%), 54$ (18.6\%) held a master's de.g.ree in nursing, and 26 (8.9\%) were certified nurses. Sixty-three (21.6\%) nurses held a professional specialization, 68 (23.4\%) had passed qualification courses, and $161(55.3 \%)$ had undertaken specialist courses. Over half of the respondents $-193(66.3 \%)$ - worked in a hospital, with most working in general wards (50.8\%). Of the remaining respondents, $12.6 \%$ worked in primary health care, $12.4 \%$ in specialist outpatient care, $3.1 \%$ in care and treatment facilities, and $2.1 \%$ in nursing homes.

The mean total score of KKS of the nurses surveyed was 171.77 points, with the range of scores $60-240$ points. The general scores of the nurses' social competences were low (36.1\%) and average (34.4\%) results. The level of competences in intimate situations (subscale I) was high for $37.8 \%$ of the nurses, while the competences in social exposure (ES subscale) were average for $40.5 \%$ of the nurses. Social competences in situations requiring assertiveness (the A subscale) were mostly average for $39.9 \%$ of the nurses.

The mean PSS-10 stress level among the surveyed nurses, as measured on a scale of $0-40$, was $16.83(\mathrm{SD}=4.47$ ), where the higher the score, the greater the severity of experienced stress (Fig. 1).

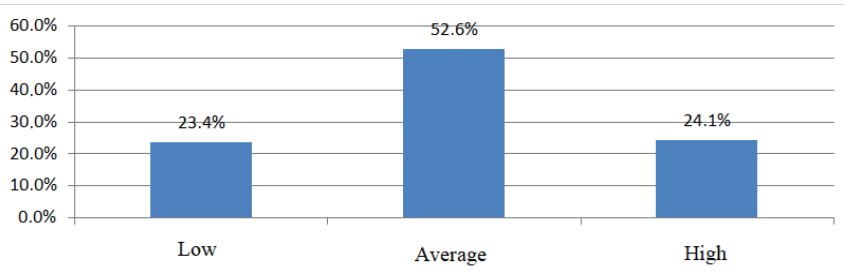

FIGURE 1. Perceived Stress Scale (PSS-10) stress levels among examined nurses by sten scores

The results of PSS-10 were interpreted in sten standard. Among nurses 52,6\% achieved average sten stores (5-6), 24.1\% achieved high sten scores (7-6), and the remaining respondents were low. Sociodemographic variables, such as sex, age, job seniority, marital status, place of residence, education and workplace, did not have a significant relation to the intensity of stress experienced by the nurses. There was no correlation between KKS-social competences and PSS-10 stress levels $(\mathrm{R}=0.059, \mathrm{p}=0.314)$.

When the 4 analyzed indicators of the GHQ-28 were considered, the mean scores were as follows: A - somatic symptoms $\mathrm{M}=8.45$, $\mathrm{B}-$ unrest and insomnia $\mathrm{M}=8.75, \mathrm{C}-$ functional disorders $\mathrm{M}=8.07, \mathrm{D}-$ symptoms of depression $\mathrm{M}=2.46$. These results indicate that among the 4 indicators, the lowest mean point score relates to symptoms of depression, which indicates a low risk of depression in the studied group (Tab. 1).

The overall GHQ-28 mental health of the nurses was interpreted on a sten scale. $38.1 \%$ of the results were in the range 5-6, which is indicative of average level of mental health experienced in the research group, $35.1 \%$ of results were in the range of high results (7-10 sten), with the remaining respondents scoring low. 
TABLE 1. Results of General Health Questionnaire

\begin{tabular}{|c|c|c|c|c|c|c|c|c|}
\hline GHQ-28 & $M$ & SD & Min. & Max. & Q1 & Me & Q3 & Range \\
\hline A - somatic symptoms & 8.45 & 3.97 & 1.00 & 21.00 & 5.00 & 8.00 & 11.00 & $0-21$ \\
\hline B - unrest and insomnia & 8.75 & 4.66 & 0.00 & 21.00 & 5.00 & 8.00 & 12.00 & $0-21$ \\
\hline $\mathrm{C}$ - functional disorders & 8.07 & 2.99 & 0.00 & 20.00 & 7.00 & 7.00 & 9.00 & $0-21$ \\
\hline D - symptoms of depression & 2.46 & 3.36 & 0.00 & 20.00 & 0.00 & 1.00 & 4.00 & $0-21$ \\
\hline General Health Score & 27.85 & 11.84 & 4.00 & 72.00 & 18.00 & 27.00 & 35.00 & $0-84$ \\
\hline
\end{tabular}

Research demonstrated that the overall mental health of the respondents correlated negatively with the indicator of social competences. It follows that the worse the mental health condition - higher scores in the GHQ-28, the lower the social competences of the respondents - lower scores in the KSS $(\mathrm{R}=-0.254, \mathrm{p}<0.001)-$ Figure 2.

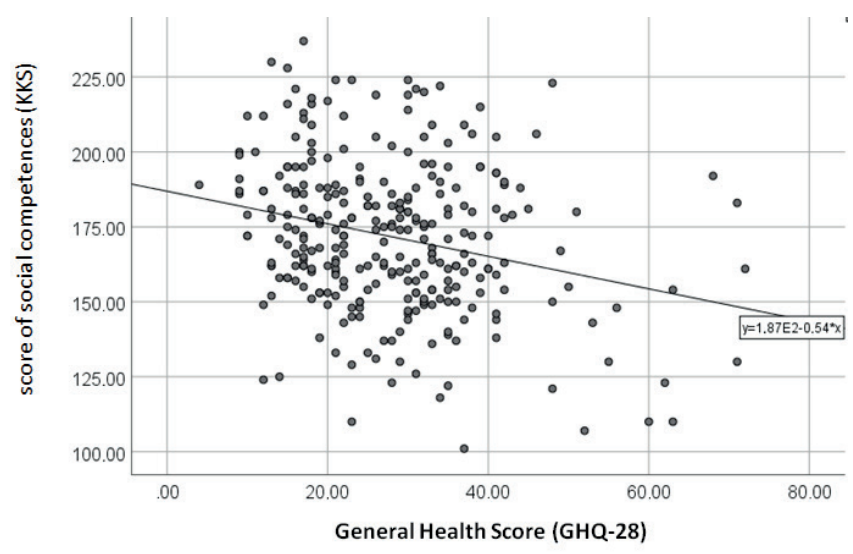

FIGURE 2. Diagram of correlation between the general mental health of nurses and the level of their social competences

The general mental health of the respondents also correlates ne.g.atively with all detailed indicators of social competences (Tab. 2).

TABLE 2. Correlations between the general state of mental health of nurses and individual components of social competences

\begin{tabular}{lccc}
\multicolumn{1}{c}{ KKS } & \multicolumn{2}{c}{$\begin{array}{c}\text { General State } \\
\text { of Mental Health }\end{array}$} \\
\cline { 2 - 4 } & $\mathbf{n}$ & $\mathbf{R}$ & $\mathbf{~}$ \\
\hline $\begin{array}{l}\text { Skills conditioning efficiency in intimate } \\
\text { situations (I) }\end{array}$ & 291 & -0.192 & 0.001 \\
\hline $\begin{array}{l}\text { Skills determining the effectiveness of } \\
\text { behavior in social exposure situations (ES) }\end{array}$ & 291 & -0.256 & $<0.001$ \\
\hline $\begin{array}{l}\text { Skills determining the effectiveness } \\
\text { of behaviors in situations requiring } \\
\text { assertiveness (A) }\end{array}$ & 291 & -0.201 & 0.001 \\
\hline
\end{tabular}

Research demonstrated a strong correlation between the general mental health condition measured by GHQ-28 and stress intensity revealed in PSS-10. The worse the mental health status of the respondents, the greater the intensity of stress experienced in the studied group $(R=-0.458$, $\mathrm{p}<0.001$ ) - Figure 3 .

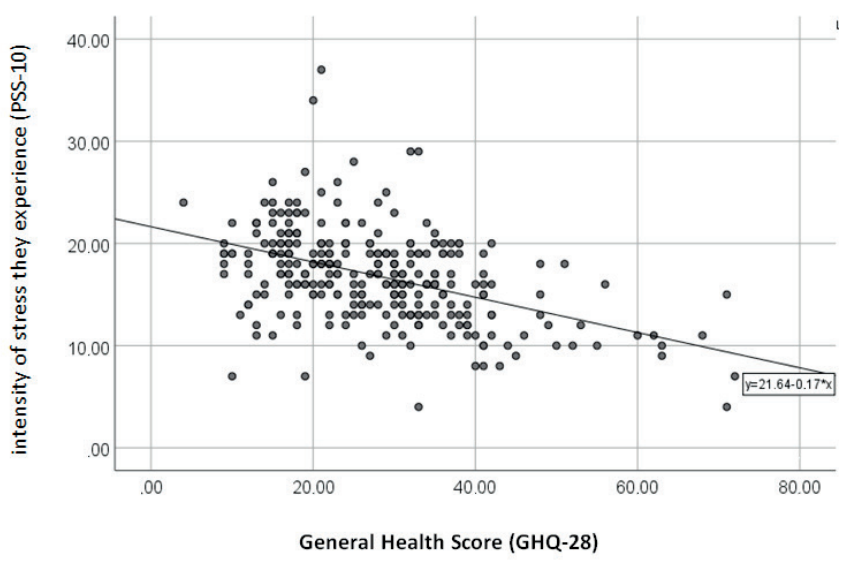

FIGURE 3. Correlation diagram of the general mental health of nurses and the intensity of stress they experience

\section{DISCUSSION}

Within our research the general mental health of the nurses was at the level of average results. In terms of severity of somatic symptoms, anxiety and insomnia, functional disorders, the mean scores of the nurses were average, and in the area of depression symptoms, low $(M=2.46)$. Social competences were identified as a factor closely related to the general health condition of the nurses examined.

In Poland, the GHQ surveys among the nurses were conducted by Cybulska et al., and the authors examined 836 nurses. In that research, they found that $54 \%$ of nurses are in good general mental health. $29.5 \%$ of nurses who show mental health disorders are characterized by their style of dealing with stress; focused on emotions ( $p=0.000)$, avoidance $(18.28 \%$ of nurses, $\mathrm{p}=0.002)$ and engaging in substitute activities $(32.11 \%$ of nurses, $\mathrm{p}=0.000$ ). The mentioned styles for coping with stress are unconstructive and form a risk factor of burnout syndrome [12].

The research by Perry et al., conducted among Australian nurses $(n=381)$, allowed the respondents to assess their general health on a scale of $1-5$, and the resulting mean score was $3.8(\mathrm{SD}=0.8)$. The interpreted results indicate good health ratings for $28.5 \%$ of the nurses, very good $45.5 \%$ and excellent for $19.4 \%$ of them [13].

In Greek studies among 246 nurses with a mean age of 39.7 years ( $\mathrm{SD}=8.2$ ), it was demonstrated that high levels of occupational stress are related to a ne.g.ative perception of health in the physical $(\mathrm{R}=-0.12)$, and mental $(\mathrm{R}=-0.35, \mathrm{p}<0.001)$ aspects. Professional stress among nurses was also associated with low job satisfaction and ne.g.ative attitudes at work, 
which has an indirect impact on the quality of healthcare [14]. Our own studies also demonstrated a ne.g.ative correlation of stress intensity with the general mental health condition of the nurses examined $(\mathrm{R}=-0.458, \mathrm{p}<0.001)$.

Occupational burnout is a significant problem in medical professions where there is exposure to stressful situations, physical and psychological stress, and involvement in complex interpersonal relationships. In the meta-analysis of research from 2004-2014 by Wilczek-Rużyczka and Zaczyk on burnout among nurses, 22 articles were analyzed. This analysis demonstrated that nurses were characterized by an average levels of emotional exhaustion, and depersonalization, and an average or high level of decline in the sense of personal achievements. These data demonstrates that Polish nurses experience moderate levels of occupational burnout [15].

In our own studies, a stress intensity that may be inducive to the formation of burnout syndrome was observed in over the half of the respondents, at an average level. The presumed correlation between social competences and intensity of stress was not proven in our research $(R=0.059, p=0.314)$. However, the studies by Uchiyama et al. indicated significant correlations $(\mathrm{p}<0.001)$ between social competences and distress in a group of 1197 Japanese nurses $(\mathrm{R}=-0.38)$. These studies indicate that social competences are a factor conditioning minor distress in the work of nurses [8].

In the studies of Pereira-Lima and Loureiro, which included 305 resident doctors at the Brazilian University Hospital, an attempt was made to assess the impact of social competences on burnout syndrome. A correlation between social competences and the following factors was demonstrated: emotional exhaustion $(\mathrm{R}=-0.239, \mathrm{p}<0.001)$, emotional distance $(\mathrm{R}=0.273, \mathrm{p}<0.001)$, anxiety $(R=-0.238, p<0.001)$, depression $(R=-0.287, p<0.001)$. This indicates a significant role of social competences as a protective factor against burnout syndrome in the physician's profession [16].

The analysis of our material indicates a positive relationship between social competences and better perception of the general mental health of nurses. There was no significant impact of social competences on the level of perceived stress levels found in our research. There is a need for further research in the field of social competences in the group of nurses. One should consider the introduction of training in the field of social skills in order to strengthen the social competences of medical professionals.

\section{CONCLUSIONS}

It is necessary to nurture social competences among nurses, predominantly due to the fact that at present their level is insufficient. Social competences in the research group do not correlate with the stress levels experienced by nurses. Nurses who do not have a deficit in general mental health according to the GHQ-28 scale demonstrate higher levels of social competences.

Social competences of nurses are an important factor for professional development, so it is worth developing the knowledge of professional determinants that strengthen this scope of competences in practice.

\section{REFERENCES}

1. Martowska K. Model uwarunkowań kompetencji społecznych. In: Skrabacz A, Gutowski J, editors. Kompetencje społeczne w kierowaniu i dowodzeniu Siłami Zbrojnymi RP. Warszawa: Wojskowe Centrum Edukacji Obywatelskiej; 2015. p. 13-28.

2. Tomorowicz A. Struktura kompetencji społecznych w ujęciu interakcyjnym. Psychiatria 2011;8(3):91-6.

3. Matczak A. Kwestionariusz Kompetencji Społecznych KKS. Podręcznik. Warszawa: Pracownia Testów Psychologicznych; 2007.

4. Knopp KA. Kompetencje społeczne - pomiar i aplikacja praktyczna. Ośrodek Rozwoju Edukacji; 2013. http://docplayer.pl/30188248-Kompetencje-spoleczne-pomiar-i-aplikacja-praktyczna.html (1.11.2018).

5. Martowska K. Psychologiczne uwarunkowania kompetencji społecznych. Warszawa: Wyd. Liberi Libri; 2012. p. 33-70.

6. Del Prette Z, Del Prette A. Social Skills Inventory (SSI-Del-Prette): Characteristics and studies in Brazil. In: Osorio F, editor. Social Anxiety Disorders: From Theory to Practice. New York: Nova Science Publishers; 2013. p. 47-62.

7. Rutkowska K. Kompetencje społeczne - bufor wypalenia zawodowego pielęgniarek. Med Ogólna Nauki Zdr 2012;18(4):319-23.

8. Uchiyama A, Odagiri Y, Ohya Y, Suzuki A, Hirohata K, Kosugi S, et al. Association of social skills with psychological distress among female Nurses in Japan. Ind Health 2011;49(6):677-85.

9. Losa-Iglesias ME, López López D, Rodriguez Vazquez R, Becerro de BengoaVallejo R. Relationships between social skills and self-esteem in nurses: a questionnaire study. Contemp Nurse 2017;53(6):681-90.

10. Juczyński, Z, Ogińska-Bulik N. Narzędzia pomiaru stresu i radzenia sobie ze stresem. Warszawa: Pracownia Testów Psychologicznych; 2009. p. 11-21.

11. Makowska Z, Merecz D. Polska adaptacja kwestionariuszy ogólnego stanu zdrowia Davida Goldberga: GHQ-12 i GHQ-28. In: Dudek B, editor. Ocena zdrowia psychicznego na podstawie badań kwestionariuszami Davida Goldberga. Podręcznik dla użytkowników kwestionariuszy GHQ12 GHQ-28. Łódź: Oficyna Wydawnicza Instytutu Medycyny Pracy im. prof. J. Nofera; 2001. p. 191-264.

12. Cybulska AM, Wieder-Huszla S, Jurczak A, Grochans E. Wpływ cech osobowości i stanu zdrowia psychicznego personelu pielęgniarskiego na wybór stylu radzenia sobie ze stresem w kontakcie z umierającym człowiekiem. Pielęg Pol 2017;65(3):427-36.

13. Perry L, Gallagher R, Duffield C. The health and health behaviours of Australian metropolitan nurses: an exploratory study. BMC Nurs 2015;14:45.

14. Sarafis P, Rousaki E, Tsounis A, Malliarou M, Lahana L, Bamidis P, et al. The impact of occupational stress on nurses' caring behaviors and their health related quality of life. BMC Nurs 2016;15:56.

15. Wilczek-Rużyczka E, Zaczyk I. Wypalenie zawodowe polskich pielęgniarek - metaanaliza badań. Hygeia Public Health 2015;50(1):9-13.

16. Pereira-Lima K, Loureiro SR. Burnout, anxiety, depression, and social skills in medical residents. Psychol Health Med 2015;20(3):353-62. 